\title{
The Effect on Leachability and Indoor Air Quality by Incorporating Waste Material into Fired Clay Brick
}

\author{
Noor Amira Sarani ${ }^{1, a}$ and Aeslina Abdul Kadir ${ }^{2, b}$ \\ ${ }^{1}$ Department of Environmental Engineering and Water Resources \\ Universiti Tun Hussein Onn Malaysia (UTHM), \\ 86400 Parit Raja, Batu Pahat Johor, \\ Malaysia \\ ${ }^{2}$ Senior Lecturer, Department of Environmental Engineering and Water Resources \\ Universiti Tun Hussein Onn Malaysia (UTHM), \\ 86400 Parit Raja, Batu Pahat Johor, \\ Malaysia \\ anramira1987@gmail.com, baeslina@uthm.edu.my
}

\section{Keywords: Waste material; Cigarette Butts, Fired Clay Brick; Leachability; Indoor Air Quality}

\begin{abstract}
Recently waste material pollution is a critical issue in every developing country. The factors such as increasing of growing population, daily and industrial activities will lead to these phenomena. These issues give an idea to use waste as a construction material that will give minimum impact towards the environment. Many researchers have been studied on waste material such as organic waste, sludge, fly ash, rice husk and processed waste tea into fired clay brick. In this study, the investigate on the incorporating of cigarette butts (CBs) was conducted. During this study, different percentages of CBs $(0 \%, 2.5 \%$ and $5.0 \%)$ were added into fired clay brick. Meanwhile, different heating rates were applied during the firing stage, which are $1^{\circ} \mathrm{C} / \mathrm{min}$, $3^{\circ} \mathrm{C} / \mathrm{min}$ and $5^{\circ} \mathrm{C} / \mathrm{min}$ respectively. All samples were fired up to $1050^{\circ} \mathrm{C}$. Leaching tests were carried out to investigate the possibility of heavy metals leached from the manufactured brick. The results demonstrated that, in terms of physical and mechanical properties, CB Brick (2.5\%) at $1{ }^{\circ} \mathrm{C} / \mathrm{min}$ improved the most and leached low heavy metals. For IAQ test, CB Brick $(2.5 \%)$ fired at $1{ }^{\circ} \mathrm{C} / \mathrm{min}$ is acceptable to be used as building materials since it complied with ICOP-IAQ.
\end{abstract}

\section{Introduction}

Cigarette butts (CBs) pose a serious litter problem to the environment. According to Novoty et al. [1], cigarette filter always carried out from streets to drains, river, and ultimately to the ocean and beaches. A study by Slaughter [2], found that CBs contains thousands of hazardous chemicals such as cadmium, arsenic and lead that are partially out during smoking. When these chemicals leached out from the filter, hazardous toxin would leach out after entering aquatic environments, waterways and land [37. The butt is comprised about $30 \%$ of the cigarette's original length and are composed of cellulose acetate (fiber). Technically, cellulose acetate is biodegradable, where it can only biodegrade under conditions described as severe biological circumstances [4]-[6]. Moreover, Ash [6] found that a cellulose acetate is extremely slow to degrade in the environment and estimated to degrade up to 18 months under the ideal condition.

Related to the environmental and health aspects, incorporation such waste into brick becomes an important issue. Waste materials can only be used if they meet the imposed limit values for total concentration of organic pollutants and leaching of heavy metals [7]. Nowadays, leaching tests is important to be performed to control the environmental quality of materials especially come into contact with human health. Several studies have been made to investigate the potential of heavy metals to the environment from manufactured brick [8]-[10]. Therefore, Toxicity Characteristic Leaching Procedure (TCLP) was conducted to determine the mobility of both organic and inorganic analysis present in liquid, solid and multiphase waste [11]. Meanwhile, choosing the right material for building construction is necessary not only in terms of energy saving, but also indoor air quality (IAQ). A study by Roulet [12] shows that properly designed and applied for the building will not 
affect the relationship between energy and indoor environment quality (IEQ), which not only air quality, but also comfort and well-being of a human. Therefore, to have a good IAQ the construction material must take into consideration especially heavy metals parameter for the bricks.

\section{Material and Methods}

In order to measure the value of each sample, the materials and method were discussed in this section.

Manufacturing and Testing Method of Clay Bricks for Experimental Analysis. In this study, two types of brick were manufactured which are CB brick and control brick with size $225 \mathrm{~mm} \mathrm{x}$ $110 \mathrm{~mm} \times 65 \mathrm{~mm}$. Different percentages of CBs $(2.5 \%$ and $5.0 \%)$ were incorporated into fired clay brick. All the brick samples were fired at three different heating rates; $1^{\circ} \mathrm{C} / \mathrm{min}, 3{ }^{\circ} \mathrm{C} / \mathrm{min}$, and $5^{\circ} \mathrm{C} /$ min respectively and fired up to $1050^{\circ} \mathrm{C}$.

The test of Toxicity Characteristic Leaching Procedure (TCLP) was conducted using USEPA method [11]. TCLP test was conducted to investigate the potential of tracked toxic pollutant from the samples. In Addition, IAQ testing was conducted in Walk in Stability Chamber (WiSC) according to European Standard: Determination of the Emission of Volatile Organic Compound from Building Products and Furnishing-Emission Test Chamber Method [13]. This experiment was conducted by using building scaled of fired clay brick with dimension of $1 \mathrm{~m} \times 1 \mathrm{~m} \times 1 \mathrm{~m}$ (cube), $0.5 \mathrm{~m} \times 0.5 \mathrm{~m} \times 1.5 \mathrm{~m}$ (column), $0.2 \mathrm{~m} \times 0.1 \mathrm{~m} \times 1.5 \mathrm{~m}$ (wall).

\section{Result and Discussion}

Leachability test and IAQ were the testing parameters conducted in this study. The results for TCLP test and IAQ were discussed below.

Toxicity Characteristic Leaching Procedure (TCLP). According to the previous results of physical and mechanical properties, TCLP was conducted because CB Brick contains high heavy metals compared to Clay Brick ( $0 \%$ CBs). A study by Moerman and Potts [14] has listed the following metals which are high in CBs; Aluminium (Al), Barium (Ba), Cadmium (Cd), Chromium $(\mathrm{Cr})$, Copper $(\mathrm{Cu})$, Ferum (Fe), Mangan ( $\mathrm{Mn})$, Nickel (Ni), Plumbum (Pb), Strontium (Sr), Titanium (Ti) and Zinc (Zn). Therefore, by considering the XRF analysis and heavy metals listed from Moerman and Potts [14], various parameters were selected to be tested in this study. The heavy metals selected are copper $(\mathrm{Cu})$, cadmium $(\mathrm{Cd})$, chromium $(\mathrm{Cr})$, zinc $(\mathrm{Zn})$, ferum $(\mathrm{Fe})$, arsenic (As) and nickel (Ni). In this test, heavy metals were referred to two sets of regulatory limits. USEPA is Land Disposal Restriction (LDR) regulations were determined if any of the thresholds established for the 40 Toxicity Characteristic (TC) constituents exceeded or have been met with the limit [15]. Meanwhile, EPAV is Guideline for Hazard Classification of Solid Prescribed Industrial Waste. From the results, it shows that there are insignificant levels of heavy metals and various results comply with the regulatory concentration limits set by USEPA and EPAV [16]. From the observation, Arsenic (As) leached over than those of the USEPA and EPAV limits (for CBs and all types of samples used).

Indoor Air Quality (IAQ). During this study, several parameters in term of chemical emissions have been tested. There are six parameters that have been tested such as Total Volatile Organic Compound (TVOC), Carbon Dioxide $\left(\mathrm{CO}_{2}\right)$, Carbon Monoxide $(\mathrm{CO})$, Ozone $\left(\mathrm{O}_{3}\right)$ and Formaldehyde $(\mathrm{HCHO})$ and Particulate Matter $\left(\mathrm{PM}_{10}\right)$ which one of the pollutants. These selected parameters are listed as indoor air contaminants and the maximum limits on Industry Code of Practice on Indoor Air Quality (ICOP-IAQ) [17]. In this stage, by comparing with different percentages of $\mathrm{CBs}, \mathrm{CB}$ Brick $(2.5 \%)$ at $1{ }^{\circ} \mathrm{C} / \mathrm{min}$ yields the optimal performance in terms of physical and mechanical properties of manufactured brick, and then it was selected to be tested for IAQ. 
Total Volatile Organic Compound (TVOC). The amount of volatile organic compound (VOCs) in indoor air, also called as Total Volatile Organic Compound had been measured using Toxic Gas Monitor which yielded different results at one particular time. VOCs are the most prevalent indoor air pollutants that originate from products and building materials [18]. According to ICOP-IAQ [17], the acceptable limit for TVOC listed as 3ppm. The result shows that TVOC in CB Brick (2.5\%) at cube pattern was perceived to be more acceptable (lower TVOC) than that in column and wall pattern. It is also lower compared to Clay Brick $(0 \% \mathrm{CBs})$. The results show that the cube pattern contained $\mathrm{CBs}$ interact with indoor air by sorption or desorption phenomena due to pores created in the brick. The CB Brick might absorb existing pollutants from empty room (ER), reducing the concentration of TVOC and finally improving the air quality. All results comply with the standard.

Carbon Dioxide $\left(\mathbf{C O}_{2}\right)$. Carbon dioxide was measured using an IAQ Meter on eight-hour-timeweighted average (twa) airborne concentration. According to Mui et al. [19], $\mathrm{CO}_{2}$ was produced by building occupants either by breathing or talking. Even though $\mathrm{CO}_{2}$ is not concerned as an important pollutant, but it is significant as an indicator of inadequate IAQ as well as poor ventilation. According to ICOP-IAQ [17], the acceptable limit for $\mathrm{CO}_{2}$ is $1000 \mathrm{ppm}$. The result shows that $\mathrm{CO}_{2}$ in $\mathrm{CB}$ Brick (2.5\%) was suggested to be more acceptable since all pattern shows lower concentration value when it is compared with Clay Brick $(0 \% \mathrm{CBs})$. All results comply with the standard.

Carbon Monoxide (CO). Carbon monoxide can be odourless, tasteless and colourless gas. The $\mathrm{CO}$ usually occurred in a combination of combustion products, which possess many distinctive odours [20]. The set limit for CO is $10 \mathrm{ppm}$. From the results, same trend for both samples has been observed. The $\mathrm{CO}$ value of cube pattern at $2.5 \%$ of $\mathrm{CB}$ Brick showed more stable than another pattern (also compared to Clay Brick $(0 \% \mathrm{CBs})$. Furthermore, the results show that the emission of $\mathrm{CO}$ for both types of brick does not exceed $50 \%$ of the $\mathrm{CO}$ recommended by the standard.

Ozone $\left(\mathbf{O}_{3}\right)$. Ozone is recognized as a pollutant by the ICOP-IAQ. Since $\mathrm{O}_{3}$ is one of the sources of indoor air pollutants, the indoor exposure to $\mathrm{O}_{3}$ will lead to serious health hazard [21]. The set limit for $\mathrm{O}_{3}$ is $0.05 \mathrm{ppm}$. In this experiment, the value of $\mathrm{O}_{3}$ empty room (ER) itself has exceeded the standard limit for $\mathrm{O}_{3}$. Nevertheless, it was surprising that the results for both types of brick are lower compared to the standard. During experimental testing, the $\mathrm{O}_{3}$ concentration for ER value is high possibly due to previously saturated condition in the chamber. However, by placing the brick inside the chamber, both of the fired clay bricks shows an improvement by lowering the $\mathrm{O}_{3}$ level inside the room. According to Lamble [22], the building materials will consider as "green" since it able to remove ozone and potential to generate undesirable byproducts such as aldehydes.

Formaldehyde (HCHO). Formaldehyde is one of the VOC pollutants. HCHO can be either from indoor or outdoor sources. For instance, HCHO emission usually from wood-based fabric, flooring material, insulation material and coatings at indoor. From the result, the wall pattern of CB Brick $(2.5 \%)$ was recommended to be used since all pattern shows higher emission of HCHO. Furthermore, the results show that the emission of HCHO for both types of brick does not exceed $50 \%$ of the HCHO recommended by the standard.

Particulate Matter $\left(\mathbf{P M}_{10}\right)$. Particulate matter can be found as solid or liquid particles found in the air. High level of $\mathrm{PM}_{10}$ in the air will lead to significant health effect that includes effects on breathing and respiratory system and another body damage [23]. By referring to ICOP-IAQ [17], the acceptable limit for $\mathrm{PM}_{10}$ is $0.15 \mathrm{mg} / \mathrm{m}^{3}$. The observation of Clay Brick $(0 \% \mathrm{CBs})$ shows the $\mathrm{PM}_{10}$ level for wall and cube pattern exceed the standard limit with $0.232 \mathrm{mg} / \mathrm{m}^{3}$ and $0.156 \mathrm{mg} / \mathrm{m}^{3}$ respectively and both of this pattern were considered not to be used directly. Meanwhile, another observation of $\mathrm{CB}$ Brick $(2.5 \%)$ shows that the level of $\mathrm{PM}_{10}$ for every pattern was lower than ER 
value as well as not higher than the standard limit for $\mathrm{PM}_{10}$. $\mathrm{CB}$ Brick $(2.5 \%)$ for all patterns are complying with the standard.

\section{Conclusion}

From the previous results obtained in this study, it is suggested that firing at heating rates $1{ }^{\circ} \mathrm{C} / \mathrm{min}$ with $2.5 \% \mathrm{CBs}$ yields the optimum performance of manufactured clay brick. By taking account on the environmental effects, $\mathrm{CB}$ Brick $(2.5 \%)$ fired at $1{ }^{\circ} \mathrm{C} / \mathrm{min}$ was found to leach less heavy metals and complied with USEPA and EPAV. The results for IAQ also are acceptable since CB Brick $(2.5 \%)$ complied with ICOP-IAQ.

\section{Acknowledgement}

The results presented in this paper are part of an ongoing postgraduate research. The authors would like to thank the Faculty of Civil and Environmental Engineering, UTHM for this study.

\section{References}

[1] T. E. Navotny, K. Lum, E. Smith, V.Wang, and R. Barnes, "Cigarettes Butts and the Case for an Environmental Policy on Hazardous Cigarette Waste," Int. J. Environ Res Public Health, Vol 6 (5), 2009, pp. 1691-1705.

[2] E. Slaughter, "Toxicity of Cigarette Butts and Their Chemical Components to the Marine and Freshwater Fishes, Atherinops Affinis and Pimephales Promelas," San Diego University: Master Thesis.

[3] G. C. Moriwaki, S. Kitajima, and K. Katahira, "Waste on Roadside, 'poi-sute' Waste: its Distribution and Elution Potential of Pollutants into Environment," Waste Management, 29, 2009, pp. 1192-1197.

[4] T. Ishigaki, W. Sugano, A. Nakanishi, M. Tateda, M. Ike, and M. Fujita, "The Degradability of Biodegradable Plastics in Aerobic and Anaerobic Waste Landfill Model Reactors," Chemosphere, vol. 54 (3), 2004, pp. 225-233.

[5] J. Puls, S. A. Wilson, and D. Hötler, "Degradation of Cellulose Acetate-Based Materials: A Review," J. Polym. Environ, 19, 2011, pp. 152-165.

[6] A. Ash, "Biodegradable Plastics Based on Cellulose Acetate," Journal of Macromolecular Science, Part a Pure and Applied Chemistry, vol. 30 (9), pp. 733-740.

[7] Degree of the Flemish Government Adopting the Flemish Regulation on Sustainable Management of Material Cycles and Waste Materials (VLAREMA), OVAM, Mechelen Belgium, 2012.

[8] H. Liu, S. K. Banerji, W. J. Butkett, and J. V. Engelenhoven, "Environmental Properties of Fly Ash Brick," World of Coal Ash, USA, 2009.

[9] D. B. Sarode, R. N. Jadhav, V. Ayubshaikh, S. T. Ingle, and S. B. Attard, "Extraction and Leaching of Heavy Metals from Thermal Power Plant Fly Ash and its Admixture," Polish. J. of Environ. Stud, 19 (6), 2010, pp. 1325-1330.

[10] J. A. Cusido, and L. V. Cremades, "Environmental Effects of Using Clay Bricks Produced with Sewage Sludge: Leachability and Toxicity Studies," Waste Management, 32, 2012, pp. 12021208.

[11]EPA Method 1311, "Toxicity Characteristic Leaching Procedure (TCLP), 1992.

[12]C. A. Roulet, "Indoor Air Quality and Energy Performance of Building," Proceeding of Healthy Building, 2006, pp. 37-48.

[13] European Standard. Determination of the Emission of Volatile Organic Compound from Building Products and Furnishing Emission Test Chamber Method, BS EN ISO 16000:9, 2006.

[14] J. W. Moerman, and G. E. Potts, "Analysis of Metals Leached from Smoked Cigarette Litter," Tobacco Control, 22, 2011, pp. i30-i35. 
[15]USEPA, Hazardous Waste Characteristics Scoping Study, US Environmental Protection Agency, Office of Solid Waste, 1996.

[16]EPAV, Guidelines for Hazard Classification of Solid Prescribed Industrial Waste, Publication 996, June, 2005.

[17] ICOP-IAQ, Industry Code of Practice on Indoor Air Quality, Department of Occupational Safety and Health, Ministry of Human Resources Malaysia, 2012.

[18] J. J. Wang, Y. B. Xie, and F. D. Yuan, "Indoor Air Quality, Pollutants, Their Resources and Methods of Elimination," Proceeding of the $10^{\text {th }}$ International Conference on Indoor Air Quality and Climate. Beijing, China, 2005, pp. 2542-2546.

[19] K. W. Mui, L. Wong, and P. S. Hui, "Feasibility Study on Benchmarking Indoor Air Quality of Air-Conditioned Offices in Hong Kong," Healthy and Creative Facilities Management, Edinburg, UK, $16^{\text {th }}-18^{\text {th }}$ June 2008, pp. 217-223.

[20]F. J. V. Rensburg, "An Investigation of Indoor Air Quality Assessment in Office Buildings," Master. Port Elizabeth Technikon, 2000.

[21] World Health Organization (WHO), Artificial Tanning Sunbeds Risks and Guidance. Marketing and Dissemination. Switzerland, 2003.

[22] S. P. Lamble, "Ozone Uptake Rates and Secondary Product Emission of Green Building Materials," Master. Missouri University of Science and Technology, 2011.

[23] L. A. Jimoda, "Effects of Particulate Matter on Human Health, the Ecosystem, Climate and Materials: A Review," Working and Living Environmental Protection, 9 (1), 2012, pp. 27-44. 